\title{
THE SYMBOLIC POETIC ACT IN S.T. COLERIDGE'S "CONVERSATION POEMS". AN INTRODUCTION TO THE SOURCES OF COLERIDGE'S NEOPLATONIC POETICS ${ }^{1}$
}

\author{
Cristina Flores Moreno \\ Universidad de La Rioja
}

\begin{abstract}
RESUMEN: En este artículo proponemos la interpretación de los llamados Conversation Poems de S. T. Coleridge como la dramatización de su joven visión Neoplatónica del acto creativo en la poesía. El análisis inicial de su filosofía de la naturaleza y de la literatura nos llevará a considerar la relevancia de la obra de Ralph Cudworth, True Intellectual System of the Universe (1678), en la poética de Coleridge, así como su reflejo en los anteriormente citados poemas.
\end{abstract}

ABSTRACT: In this paper we propose the interpretation of S. T. Coleridge's Conversation Poems as the dramatisation of Coleridge's early Neoplatonic view of the poetic creative act. An initial analysis of this Romantic philosophy of nature and literature will lead us to consider the relevance of Ralph Cudworth's True Intellectual System of the Universe (1678) to Coleridge's early poetics, as well as its reflection in the already mentioned poems.

PALABRAS CLAVE: S. T. Coleridge; poesía; Romanticismo; Neoplatonismo; símbolo.

KEYWORDS: S. T. Coleridge; poetry; Romanticism; Neoplatonism; symbol.

\section{Introduction}

Samuel Taylor Coleridge's Conversation Poems, six poems written between 1795 and 1798, can be read as the dramatisation of the poetic creative act as the author conceived it at this early stage of his career. It was in the 1790s when Coleridge started articulating his philosophy of nature and poetry, which he will further develop throughout his life as he progressively absorbed new influences.

1. Financial support for this research was provided by the Consejería de Educación del Gobierno de La Rioja grant (B.O.R. 322/1999). 
It is our belief that his reading of the works by, among others, Plotinus, Boehme, Berkeley, Akenside and Cudworth during these years, are the bases of the Neoplatonic character of his early poetics.

In this paper we present an initial approach to the general sources of Coleridge's Neoplatonism. We will mainly focus on the influence exerted on his thought by Ralph Cudworth's The True Intellectual System of the Universe (1678), the most celebrated work of the Cambridge Neoplatonist school, which Coleridge read twice in the years 1795 and 1796. There, Cudworth defends the harmonious unity of the universe that is dependent on, and partakes of, the all-embracing spiritual Nature. This idea will be borrowed by Coleridge to elaborate a theory of poetry in which the poet is capable of reaching, at the peak of the "symbolic" creative act, this all-embracing Spirit, and so, of communicating it.

The rondo structure of the Conversation Poems, and the metaphysical speculations included at the core of these six poems, namely "The Aeolian Harp" (1795), "Reflections on Having Left a Place of Retirement" (1795),"This Lime-Tree Bower My Prison"(1797),"Frost at Midnight" (1798),"Fears in Solitude"(1798) and "The Nightingale"(1798)2, can be interpreted, as we will propose here, as the representation of Coleridge's emergent Neoplatonic poetics.

\section{2 .S.T.Coleridge's philosophy of nature and literature in the 1790s}

Always considering the developing, ever-changing nature of S.T.Coleridge's thought, we will try to recreate what his philosophy of literature was like during this fruitful decade, the 1790s, his particular view of the composition of nature and the place and role of the poet in it. It was, at that point in his life, the Neoplatonic philosophy that helped him to create his wholistic view of Nature, that almost led him to pantheism, as well as to place the poet at the centre of Nature's architecture.

In the period 1790-1800 Coleridge did not produce many explicit commentaries on the nature of poetry. Thus, we must turn to the analysis of his poetical production in search of his thoughts about poetry for, as he claimed at that time, his poetry "sweats beneath a heavy burthen of Ideas" (CL,I,137).

Coleridge's poems in that decade present Coleridge's attempt to get an insight into the unity of Nature and further identification of man and Nature. To this we should add his open interest in the mental processes involved in the poetic creative act.

A letter he wrote to Thelwall in October 1797 sheds light on Coleridge's concept of nature at that moment:

2. "The Aeolian Harp" August 20th 1795; "Reflections on Having Left a Place of Retirement" late 1795; "This Lime-Tree Bower My Prison" July 1797; "Frost at Midnight" February 1798; "Fears in Solitude" April 20th 1798; "The Nightingale" April 1798. 
I can at times feel strongly the beauties, you describe, in themselves, and for themselves - but more frequently all things appear little - all the knowledge, that can be acquired, child's play - the universe itself- what but an immense heap of little things? - I can contemplate nothing but parts, and parts are all little - ! - My mind feels as if it ached to behold and know something great - something one and indivisible - and its is only in the faith of this that rocks or waterfalls, mountains or caverns give me the sense of sublimity or majesty! - But in this faith all things counterfeit infinity! ${ }^{3}$

Nature is, therefore, a great unity. Phenomena are different parts of this complete Whole that allow man to reach, through contemplation, this unity of Nature, because "all things counterfeit infinity". Then, nature has a twofold aspect: it is both realistic as well as symbolic:

For all that meets the bodily sense I deem

Symbolical, one mighty alphabet

For infant minds

(The Destiny of Nations, 1796)

Symbol (phenomena) and referent (Nature) participate in a common nature by virtue of the "Plastick Life" of nature. This is the foundation of Coleridge's "symbolic knowledge" (Appleyard 1965:50). To us, his philosophy of literature is based on this symbolic knowledge:

In looking at objects of Nature while I am thinking [...] I seem rather to be seeking $[\ldots]$ a symbolical language for something within me that already and forever exists. $(\mathrm{CN}, \mathrm{II}, 2546)^{4}$

In these speculations we can see the source of his mature idea of symbol as he defines it in his latest works, especially The Stateman's Manual(1816) and Aids to Reflection(1825):

by symbol I mean, not a metaphor or allegory or any other figure of speech or form of fancy, but an actual and essential part of that, the whole of which it represents. (SM:p.79)

A Symbol is a sign included in the Idea, which it represents: ex.gr. an actual part chosen to represent the whole...(AR:p.363-4)

3. Quoted in Appleyard (1959:55).

4. Note dated April 14th 1805. 
In March 1798, in a letter to his brother George, Coleridge already presents himself as a poet of nature, inspired by "fields \& woods \& mountains with almost a visionary fondness" and seeking to "elevate the imagination \& set the affections in right tune by the beauty of the inanimate impregnated, as with a living soul, by the presence of Life" (CL,I,397).

This "living soul", "the presence of Life", which the poet should recognize in the symbolic phenomenon through the imagination ${ }^{5}$, seems to be the result of his attraction to the Neoplatonic tradition, but most important, to Ralph Cudworth's The True Intellectual System.

\section{Ralph Cudworth's influence on Coleridge}

Coleridge's attraction to the Platonic and Neoplatonic tradition, which started to fascinate him during his attendance to Christ's Hospital ${ }^{6}$, was further strengthened in Cambridge and continued to hold his interest during his staying in Bristol with his friend Southey ${ }^{7}$ were he undertook the study of the Cambridge Platonists. These were a group of Anglican philosophers who, in the seventeenth century, emerged against the materialist philosophy of the time, especially against Hobbes, with the aid of Plato's, but mostly of Plotinus' ideas ${ }^{8}$. Ralph Cudworth (1617-1688) and Henry More (1614-1687) were the main leaders of this Neoplatonic School ${ }^{9}$.

5. Coleridge would not totally develop his theory of Imagination, as it is generally known, until 1815 when he writes Biographia Literaria. Thus, despite the fact that he uses the term "imagination" here, we must be careful not to mistake it for his mature concept of this faculty.

6. Charles Lamb, in "Christ's Hospital Five-and-Tirty Years Ago" (Quoted in Holmes 1999:32), recalls Coleridge's early study of some of the Neoplatonic philosophers when both of them attended Christ's Hospital from 1782 to 1791:

Come back into memory, like as thy wert in the dayspring of thy fancies, with hope like a fiery column before thee - the dark pillar not yet turned - Samuel Taylor Coleridge - Logician, Metaphysician, Bard! - How I have seen the casual passer through the Cloisters stand still, entranced with admiration, [...], to hear thee unfold, in thy deep and sweet intonations, the mysteries of Jamblichus, or Plotinus (for even in those years thou waxedst not pale at such philosophic draughts.

In Biographia Literaria, Coleridge himself comments on his "early study of Plato and Plotinus, with the commentaries and the THEOLOGIA PLATONICA, of the illustrious Florentine; of Proclus, and Gemistus Pleth" (BL,I,ix,144).

7. It can be seen in a letter of 19 November 1796, where he requests John Thelwall to purchase for him copies of Jamblichus, Proclus, Porphyry, and Plotinus, the authors Cudworth frequently quoted in the course of his The True Intellectual System of the Universe. 
In order to defend the existence of God, these Neoplatonic philosophers proposed the spiritual constitution of nature. They did not analyse nature into individual elements or into particular forms, on the contrary, they proposed a universal synthesis, following Plotinus' cosmology. Nature is, to them, plastic rather than mechanical. In Cassirer's words, "instead of resolving complex reactions into their simple elements, they like to proceed from the whole to the parts, and show how the one original vital force governing nature is infinitely exemplified, yet not lost, in these exemplifications".(Cassirer 1953:50-51)

It was in 1795 when Coleridge became acquainted with Cudworth's Intellectual System, first published in 1678. According to the Registers of the Bristol Library Society (Whalley:1949), Coleridge borrowed Cudworth's book twice and studied it in the periods going from 15 May to 1 June 1795 and again from 9 November to 13 December 1796.

In this his masterwork, Cudworth challenges the empiricism of the age by claiming that the universe was not, as Hobbes believed, composed merely of material atoms governed by mechanical laws. On the contrary, the natural world was symbolic of a transcendent reality beyond appearances, thanks to the "spermatic reason or plastic nature" that allowed the interrelation between the corporeal and the incorporeal.

Though Cudworth distinguishes between two principles of being: a corporeal, (quantity) and an incorporeal substance (energy), intrinsically different and incommensurable, he admitted a reciprocal influence of one substance upon the other in the intermediary sphere of the lower energies of the soul. This intermediary sphere is the imagination, corresponding to Plastic Nature as the link between both substances, the forming principle from within, the medium employed by God to shape the universe ${ }^{10}$ :

There must be some other Immediate Agent and Executioner provided for the producing of every Effect [...] Wherefore the Divine Law and Command, by which the things of Nature are administered, must be conceived to be the Real Appointment of some Energetick, Effectual and

8. Coleridge was well aware of this Plotinian strain in these philosophers' thought, that is why he claimed: "The greater number were Platonists, so called at least, and such they believed themselves to be, but more truly Plotinists". (Coleridge on the Latitudinarian party at Cambridge, quoted in Schrikx 1966:71). This is also the main topic in Kabitoglou (1991), who studies the influence of Plotinus in the Cambridge Platonists, taking as a starting point this statement by Coleridge.

9. Also members of this philosophical movement were Benjamin Whichcote (1609-1683), John Smith (1618-1652) and Nathanael Culverwell (1615?-1650?).

10. More information about Cudworth's ideas in ASPELIN, Gunnar (1943), GYSI, Lidia (1962) and PASSMORE, J.A (1990). 
Operative Cause for the Production of every Effect [....] there is a Plastick Nature under him [God], which as an Inferior and Subordinate Instrument doth drudgingly execute that Part of his Providence which consists in the Regular and Orderly Motion of Matter. (Cudworth 1743, I,147)

Therefore, all things in the universe depend on a "forming principle from within", he calls "Plastick Nature". This concept is a close relative of Henry More's concept of "Spirit of Nature" he describes as follows: "there need be no other logoi spermatikoi, or Seminal Forms, than this one, which virtually contains all every where, and is therefore rightly styled The Universal Spirit of Nature"11.

Both of them are direct descendant of the tradition of the logoi spermatikoi or rationes seminales introduced by the Stoics, qualified by the Neoplatonists, and adopted finally by any number of thinkers during the Renaissance ${ }^{12}$.

This theory of "The Plastick Life of Nature" is, to Spencer-Hill (1978:9), one of the sources of Coleridge's imagination. And also, we would add, the basis of his poetics.

\section{The "Conversation Poems"}

Cudworth's work exerted a great influence on Coleridge. "Effusion XXXV"13, "The Slave Trade Lecture", the first Lecture on Politics and Religion ("Remarks ... on Atheism"), "The Destiny of Nations", "Religious Musings", and some entries in his notebooks, all of them written in 1795 or shortly later, show the impact of Cudworth's work on Coleridge ${ }^{14}$.

In a letter written the 31st December 1796, a forthnight after his second borrowing of the Intellectual System, Coleridge claims:

Dr Beddoes, \& Dr Darwin think that Life is utterly inexplicable, writing as Materialists - You, I understand, have adopted the idea that it is the result of organized matter acted on by external Stimuli. - As likely as any other system; but you assume the thing to be proved- the 'capability of being

11. More's Preface, p.xv.Quoted in Patrides (1969:27).

12. See Hunter (1950) for a description of the different ramifications of the theory along the seventeenth century in England.

13. The earliest version in print of "The Eolian Harp".

14. Schricks (1966), analyses the influence of Cudworth's True Intellectual System in three letters written by Coleridge in the three years that followed his reading this work. Howard, Claud (1978) studies the influence of both the Cambridge Philosophers and Kant on Coleridge's ontology, epistemology as well as on his concepts of Reason and Understanding, and his religious philosophy. 
stimulated into sensation' as a property of organized matter- now 'the Capab.' \&c is my definition of animal Life - Monro believes in a plastic immaterial Nature - all-pervading-

And what if all of animated Nature

Be but organic harps diversely fram'd

That tremble into thought as o'er them sweeps

Plastic \& vast \&c -

(by the bye - that is my favorite of my poems- do you like it?)...

(Coleridge 1978:50-51)

These lines belong to the first version in print of "The Eolian Harp":

And what if all of animated nature

Be but organic Harps diversely fram'd

That tremble into thought, as o'er them sweeps

Plastic and vast, one intellectual breeze,

At once the Soul of each, and God of all? (ll.36-40)

Beer (1987:68) describes this poem as "the vision of animated nature as breathed upon and physically informed by a single shaping spirit". This is Coleridge's early wholistic view of nature. The "Plastic intellectual breeze" appears as an outflowing from the Supreme Intelligence that embraces all things in the universe, including our soul. According to this view, all natural objects as well as men's souls reach a unity with the infinite Plastick Intelligence.

It is in "The Eolian Harp" were we find most clearly Cudworth's influence on his poetry, as we already exposed in Flores Moreno (2000). Nevertheless, the Neoplatonic view of nature is also noticeable in the rest of the "Conversation Poems".

The idea that the living spirit transfuses itself into phenomena is again central in "Frost at Midnight"(1798):

But still the living spirit in our frame, That loves not to behold a lifeless thing, Transfuses into all its own delights, Its own volition, sometimes with deep faith And sometimes with fantastic playfulness. (1l.21-25) ${ }^{15}$

Though they were defined as "nature poems" by Coleridge, we would rather define them as poems of one's approach to nature. They present not only a certain ontological view but also an epistemological quest that is represented by means of a certain structural pattern.

15. Quarto pamphlet printed by Johnson in S.Paul's Churchyard 1798. 
These poems are written following a tripartite rondo structure that starts in the description of the poet's surrounding landscape, and after a visionary moment in which the lyrical voice recognises the Absolute working through the phenomena, goes back to the starting-point.

Thus, in "This Lime-tree Bower my Prison"(1797), the initially repressive nature, represented by the lime-tree bower, becomes the vehicle to reach the knowledge of the Almighty Spirit:

... So my friend

Struck with deep joy may stand, as I have stood, Silent with swimming sense; yea, gazing round On the wide landscape, gaze till all doth seem Less gross than bodily; and of such hues As veil the Almighty Spirit, when yet he makes Spirits perceive his presence. (ll.38-43)

We agree with Engell's description of the poem as "what might be called a romantic or symbolic version of ut pictura poesis". "Imaginative poetry", Engell follows, "becomes the vehicle to transmit vision, yoking together the most mundane and the most profound sense of that word." (Engell 1990: 82)

The poet finds in the sensible objects of nature the way to reach the Spirit of Nature through imagination. That is what we find at the core of "Reflections on Having Left a Place of Retirement"(1795):

It seem'd like Omnipresence! God, methought, Had built him there a temple: the whole World Seem'd imag'd in its vast circumference: No wish profan'd my overwhelmed heart. Blest hour! It was a luxury, -- to be! (1.38-42)

The lyrical voice notices the symbolic power of nature, the material world he is looking at is contained and contains the Whole of Nature. Symbolic phenomena become eternal divine language as in "Frost at Midnignt" (1798):

But thou, my babe! Shalt wander like a breeze By lakes and sandy shores, beneath the crags Of ancient mountain, and beneath the clouds, Which image in their bulk both lakes and shores And mountains crags: so shalt thou see and hear The lovely shapes and sounds intelligible 
Of that eternal language, which thy God Utters, who from eternity doth teach Himself in all, and all things in himself. Great universal Teacher! He shall mould Thy spirit, and by giving make it ask. (1l.54-65)

"Fears in Solitude" (1798) also begins with the description of the "Sweet influences" of Nature. In the forms of nature, the poet would be able to see "Religious meanings":

And he, with many feelings, many thoughts, Made up a meditative joy, and found Religious meanings in the forms of nature! And so, his senses gradually wrapt In a half sleep, he dreams of better worlds, And dreaming hears thee still, O singing-lark;

That singest like an angel in the clouds! (ll. 22-28)

Material objects in nature become a symbolic language that the poet must be able to interpret. Magnunson (1989:207) notes that both "Frost at Midnight" and "Fears in Solitude" make the language of their expression their major theme. "Frost at Midnight" questions the intelligibility of nature's language, "that eternal language, which thy God/ Utters", while "Fears in Solitude" attributes the failure of language to its misuse by those who deliberately distort and misrepresent.

The ideal poet's main task is the correct interpretation of these nature symbols in order to acquire knowledge of the Absolute Nature and, at the same time, identify himself with it. This is one of the main topics in "The Nightingale" (1798):

And many a poet echoes the conceit;

Poet who hath been building up the rhyme

When he had better far have stretched his limbs

Beside a brook in mossy forest-dell,

By sun or moon-light, to the influxes

Of shapes and sounds and shifting elements

Surrending his whole spirit, of his song

And of his fame forgetful! So his fame

Should share in Nature's inmortality,

A venerable thing! And so his song

Should make all Nature lovelier, and itself

Be loved like Nature! ... (ll.23-34) 
Spencer-Hill (1983:53) notes that this poem "establishes a contrast between literal and literary Nature". The nightingale, "Nature's sweet voices" (1.42), Coleridge complains, is usually misinterpreted by those poets who "had been building up the rhyme" artificially instead of going out into the natural world itself. Thus, this kind of poet, "poor wretch! filled all things with himself, / And made all gentle sounds tell back the tale of his own sorrow" (ll.19-21), is not able to see Nature in itself.

As we have seen, S.T. Coleridge's philosophy of literature was initially founded on the cosmological and epistemological structures provided by Cudworth in his The True Intellectual System of the Universe. His so-called "Conversation Poems" show the impact of this work on Coleridge's thought. Phenomena become symbols, which share a common nature with the Absolute Whole of Nature - Cudworth's "Plastick Life"-, that must be correctly interpreted by the poet, not as mere objects of nature but as parts that contain the totality of Nature.

\section{Bibliography}

APPLEYARD, J.A. Coleridge's philosophy of literature: the development of a concept of poetry 1791-1819. Harvard: Harvard University Press, 1965.

ASPELIN, Gunnar. Ralph Cudworth's interpretation of greek philosophy. A study in the history of English philosophical ideas. Göteborg: Elanders Boktryckeri Aktiebolag, 1943.

BEER, John. Coleridge's poetic intelligence. London: Macmillan, 1986 [1977].

CASSIRER, Ernst. The platonic renaissance in England. London: Nelson, 1953. COLERIDGE, S.T. Collected letters. Edited by E. L. Griggs. New York: Oxford University Press, 1956-1971.

— Collected notebooks. Edited by K. Coburn \& N. Christensen. In: COBURN, K. The collected works of S. T. Coleridge. Princeton: Princeton University Press, 1973.

— Biographia literaria. Edited by James Engell and H. J. Jackson. In: COBURN, K. The collected works of S. T. Coleridge. Princeton: Princeton University Press, 1983, 7.

— The stateman's manual in Lay Sermons. Edited by R. J. White. In: COBURN, K. The collected works of S. T. Coleridge. Princeton: Princeton University Press, 1993, 6.

- Aids to reflection. Edited by J. Beer. In: COBURN, K. The collected works of S. T. Coleridge. Princeton: Princeton University Press, 1993, 9.

- The works of Samuel Taylor Coleridge. Wordsworth, 1994. 
CUDWORTH, Ralph. The true intellectual system of the universe wherein all the reason and philosophy of atheism is confuted and its impossibility demonstrated. London: Printed for R.Royston, 1743 (1678).

ENGELL, James. "Imagining into Nature. This Lime-Tree Bower My Prison". In: BARTH, J. R. and John L. MAHONEY (eds.). Coleridge, Keats and the Imagination. Columbia; London: University of Missouri Press, 1990, p. 81-96.

FLORES MORENO, Cristina. "Plastic intellectual breeze: The neoplatonic strain in Coleridge's early versions of "The Eolian Harp"'". Proceedings of the XXIV AEDEAN Conference (forthcoming), 2000.

GYSI, Lidia. Ralph Cudworth. Mystical thinker. Greek Monastery of the Assumption: Newport Pagnell, 1973.

HOLMES, Richard. Coleridge: Early visions. London: Flamingo, 1999.

HOWARD, Claud. Coleridge's idealism. A study of its relationship to Kant and to the Cambridge platonists. Boston: Gorham Press, 1978.

HUNTER, William B. "The Seventeenth century doctrine of plastic nature”. Harvard Theological Review, 1950, 43, p. 197-213.

KABITOGLOU, E. Douka. "The Cambridge platonists: A reading from Coleridge". The Seventeenth- Century, 1991, 6 (1), p. 11-31.

MAGNUNSON, Paul. "The shaping of 'fears in solitude'". In: GALLANT, Christine (ed.). Coleridge's theory of imagination today. New York: AMS Press, 1989.

PASSMORE, J. A. Ralph Cudworth. An interpretation. Bristol: Thoemmes, 1990 [1951].

PATRIDES, C. A. The Cambridge platonists. London: Edward Arnold, 1969.

ROOKMAAKEN, H. R. Towards a romantic conception of Nature. Coleridge's poetry up to 1803. A study in the history of ideas. Amsterdam, Philadelphia: John Benjamins, 1984.

SCRICKX, W. "Coleridge and the Cambridge platonists". A review of English literature, 1966, p. 71-91.

SPENCER-HILL, John. Imagination in Coleridge. London: Macmillan Press, 1978.

- A Coleridge companion. London: Macmillan Press, 1983.

WHALLEY, George (ed.). The Bristol library borrowings of Southey and Coleridge, 1793-1798. London: The Biographical Society (Oxford: O.U.P), 1949.

WU, Duncan (ed.). Romanticism: An anthology. London: Blackwells, 1998 
